\title{
The tipping point: Can Walmart's new animal welfare policy end factory farming?
}

\author{
Carrie A. Scrufari* \\ Vermont Law School
}

Submitted September 15, 2015 / Revised December 13 and 14, 2015, and January 25, 2016 /

Accepted January 25, 2016 / Published online June 17, 2016

Citation: Scrufari, C. A. (2016). The tipping point: Can Walmart's new animal welfare policy end factory farming?. Journal of Agriculture, Food Systems, and Community Development, 6(3), 103-120.

http://dx.doi.org/10.5304/jafscd.2016.063.009

Copyright (C) 2016 by New Leaf Associates, Inc.

\begin{abstract}
Undercover investigations revealing abuse and headlines concerning deadly viruses are increasing awareness regarding how we treat farm animals intended for human consumption. Pictures on food products depicting hens and cows peacefully roaming in the grass outside a barn belie the current reality of factory farming and the suffering animals endure under this system. This policy analysis examines how animal welfare has been regulated in this country and exposes the multitude of exemptions that exist for farm animals. The federal Animal Welfare Act, Twenty-Eight Hour Law, Federal Meat Inspection Act, Humane Methods of Slaughtering Act, and the Poultry Products Inspection Act all fail to adequately regulate the treatment, care, and travel of agricultural animals. If states attempt to take matters into their own hands, they run into a host of preemption problems. Even for the regulations that do
\end{abstract}

* Carrie A. Scrufari, Esq., LL. M. Fellow, Center for Agriculture and Food Systems, Vermont Law School; P.O. Box 499; South Royalton, Vermont 05068 USA; +1-443-6102308; CarrieScrufari@vermontlaw.edu reach agricultural animals, not a single one embraces the Five Freedoms that are recommended according to the Farm Animal Welfare Council. These recommendations include that animals be free from hunger, thirst, discomfort, pain, and distress, and that they be able to express their normal behavior. In an unprecedented move, Walmart recently announced that its suppliers will adhere to animal welfare standards embracing the Five Freedoms. However, Walmart's policy has several shortcomings, including a voluntary compliance regime and no deadline for implementation. Nevertheless Walmart's animal welfare policy is likely this country's best hope for shifting current practices away from factory farming in favor of more humane and healthy handling of agricultural animals.

\section{Keywords}

factory farming, animal welfare, Animal Welfare Act, Twenty-Eight Hour Law, Federal Meat Inspection Act, Humane Methods of Slaughtering Act, Poultry Products Inspection Act, preemption, Five Freedoms, Farm Animal Welfare Council, voluntary compliance, Commerce Clause 
"Look at the world around you. It may seem like an immovable, implacable place. It is not. With the slightest push - in just the right place — it can be tipped."

(Gladwell, 2002, p. 259)

\section{Introduction}

The lives of chickens who lay the eggs we buy at large grocery stores today bear little to no resemblance to that of chickens raised on small family farms decades ago. Today, they are restrained in wire cages with less than a sheet of paper's worth of square footage, often housed with dead and decaying cage mates, and are not provided any opportunity to perch, roost, forage, spread their wings, or experience the outdoors. Baby chicks have their beaks seared off with a guillotine-like machine, without painkillers, so that they do not peck their cage mates to death as a result of their extreme stress and frustration at living in such cramped conditions. The wire caging often mangles the birds' feet, heads, and necks, thereby creating bleeding, open sores (Soloman, 2015). Over 93 percent of the 7.41 billion eggs produced every year in this country are sourced from operations using this battery cage system (Strom, 2015).

Undercover investigations have revealed other abuses to broiler chickens raised for meat. This year, Tyson Foods—a major Walmart supplier headquartered in Mississippi-and workers were charged with 33 counts of criminal cruelty to animals after the nonprofit advocacy organization Mercy For Animals released an undercover investigation showing workers punching and throwing chickens and ripping off their heads (Mercy For Animals, 2015). A similar undercover investigation this year showed workers beating pigs in the face with boards and packing them into dirty, overcrowded pens with other sick and injured pigs (Mercy For Animals, 2015). Similar activities were documented at Seaboard Foods, a Walmart pork supplier in Colorado (Mercy For Animals, 2015).

In response to these undercover investigations and consumer petitions expressing outrage, Walmart announced that its food suppliers should adhere to higher standards for animal welfare, including limiting prophylactic antibiotic use and eliminating the use of gestation crates for pigs and battery cages for egg-laying hens. Gestation crates are narrow, 2-foot wide metal crates that house sows (female pigs) while they are pregnant; the crates do not provide enough space for the sows to turn around (Humane Society of the United States [HSUS], 2014). Similarly, battery cages are small, wire cages that house laying hens for the duration of their lives; they provide each hen with 67-76 square inches (432-490 square $\mathrm{cm}$ ) of space. The battery cage provides less space than a standard sheet of paper ( 94 square inches or 603 square $\mathrm{cm}$ ) and prevents hens from spreading their wings (Friedrich, 2013). Recognizing the cruelty inherent in gestation crate and battery cage operations, Europe has banned their use since 2013. In part because Walmart's animal welfare announcement addressed these two housing practices, it received wide support from animal rights groups, and the HSUS endorsed Walmart's move. Although Walmart's announcement signals a significant turning of the tide with respect to animal welfare and a tipping point in terms of the market power that can be wielded to encourage stronger animal welfare standards, it falls short of what is necessary to implement timely, lasting, and meaningful reforms.

Walmart's plan relies on voluntary compliance from its suppliers and does not contain any hard deadlines or timelines specifying when suppliers should meet these new animal welfare standards. Walmart could receive positive press for its decision to prioritize animal welfare without actually ensuring that its suppliers are complying with the new policy. Notably, Costco made a similar announcement with respect to battery cages seven years ago, but, as a recent HSUS undercover investigation has revealed, Costco is still sourcing from suppliers who raise animals in abhorrent conditions. After weeks of bad press following the undercover investigation, Costco has again committed to source its eggs from battery cage-free operations, claiming that it "expects to sell over one billion cage free eggs" in 2016 (Shanker, 2015). However, it still remains to be seen whether Costco can follow through on any of its cage-free pledges. Animal welfare advocates should be asking the same questions of Walmart's pledge.

This policy analysis argues that although 
Walmart's position on animal welfare is laudable, relegating animal welfare to the market under a voluntary compliance regime with no deadline in place is insufficient. Nevertheless, Walmart's announcement likely remains this country's best hope for improving the lives of agricultural animals. In the face of an ineffective federal regulatory regime for animal welfare, Walmart could succeed where Congress has not. State regulatory protection for farmed animals is vulnerable to several challenges, including preemption ${ }^{1}$ and dormant Commerce Clause challenges, ${ }^{2}$ as will be discussed. Although all states have animal cruelty laws that do not run afoul of preemption and dormant Commerce Clause doctrines, most of these laws either impliedly permit inhumane treatment of animals raised for agricultural use or expressly exempt these animals altogether. Without satisfactory federal or state protections for farmed animals, consumers and advocates have filled the gap by demanding change in the market place. Various retailers have made strides in the realm of animal welfare over the years, but Walmart is uniquely positioned to be the force that ultimately redefines commonly accepted agricultural practices. Walmart's influence on retailer, vendor, and other producer behaviors is unprecedented. However, although it has an unparalleled opportunity to shift the status quo through its policies and initiatives, Walmart will need to require more if it truly intends to promote animal welfare, sustainability, and transparency in our food supply. Animal welfare advocacy groups and consumer pressure pushed Walmart to prioritize animal welfare; now these groups are tasked with ensuring that Walmart remains accountable to its pledge.

The first section of this policy analysis

\footnotetext{
1 The preemption doctrine is used to determine whether state or federal law governs in a particular circumstance. There are three different kinds of preemption. Express preemption exists where a federal law expressly states that it controls and the states may not enact contrary legislation (see Jones $v$. Rath Packing Co., 1977). Conflict preemption exists where it would be impossible to comply with both the federal and the state law because the state law is different; in such circumstances, the federal law trumps the state law and controls (see Jones $v$. Rath, 430 U.S. at 525-526, 1977). Field preemption exists when Congress is said to have occupied the field of a certain area by
}

provides a historical overview of how animal welfare has been regulated in the United States and addresses the gaps and loopholes in the animal welfare regulations that exist for agricultural animals. The second section discusses the preemption and Commerce Clause challenges states face when they try to take matters into their own hands to regulate animal welfare. The third section addresses the commonly accepted agricultural practices that are permitted in the agricultural industry and the lack of regulation over these practices that many animal welfare advocates consider inhumane. The final section critiques the market's solution to this lack of regulation: letting market forces drive animal welfare conditions, as evidenced by various retailers' announcements to prioritize animal welfare. This policy analysis concludes that, while flawed in fundamental respects, Walmart's recent announcement - coupled with continuing pressure from consumers and animal welfare advocates-is currently our best hope for achieving stronger animal welfare standards in this country.

\section{A Brief History of Federal Animal Regulation in the United States}

\section{The Animal Welfare Act}

Congress passed the Animal Welfare Act of 1966

(Pub. L. No. 89-544, 80 Stat. 350, codified as amended at 7 U.S.C. SS 2131-2159 [2008]) with the intent to provide "humane care and treatment" to animals in interstate commerce (7 U.S.C. \2131 (1) [2008]), and "to assure the humane treatment of animals during transportation in commerce" (7 U.S.C. \2131 (2) [2008]). Additionally, Congress stated that it was "essential to regulate the transportation, purchase, sale, housing, care, handling,

\footnotetext{
leaving "no room for the States to supplement it" (Rice v. Santa Fe Elevator Corp., 1947).

${ }^{2}$ As will be discussed later, the Commerce Clause of the U.S. Constitution grants Congress the authority to regulate commerce among the states (see U.S. Const. Art. I, $\ 8, \mathrm{Cl}$. 3). The dormant Commerce Clause doctrine provides that state statutes intended to achieve a legitimate local public interest and that produce only incidental effects on interstate commerce will be upheld so long as any burden on interstate commerce is not excessive in relation to the local benefits the law achieves (see Pike v. Bruce Church, Inc., 1970).
} 
and treatment of animals" (7 U.S.C. \ 2131 [2008]). The Animal Welfare Act defines an "animal" as "any live or dead dog, cat, monkey (nonhuman primate mammal), guinea pig, hamster, rabbit, or such other warm-blooded animal" (7 U.S.C. $\$ 2132$ (g) [2008]). The Act notably exempts, among other animals, all "farm animals, such as, but not limited to livestock or poultry, used or intended for use as food or fiber, or livestock" (7 U.S.C. $\$ 2132$ (g) [2008]). Thus farm animals such as cows, pigs, and poultry raised for human consumption are exempt from all animal welfare regulations contained within the Act.

\section{The Twenty-Eight Hour Law}

Congress passed the Twenty-Eight Hour Law of 1873, prohibiting producers from confining "animals in a vehicle or vessel for more than 28 consecutive hours without unloading the animals for feeding, water, and rest" (49 U.S.C. \ 80502 (a) (1) [1994]). Historically, the law applied only to "rail carrier[s]" or other "common carrier[s]" that were "transporting animals" (49 U.S.C. \ 80502 (a) (1) [1994]). The law specifically exempts animals transported by air or water (49 U.S.C. $\$ 80502$ (a) (1) [1994]). Over the last century, as animals have been increasingly transported by truck rather than rail, the law has essentially provided no protection to animals. Indeed, the law has not been enforced in more than 40 years (HSUS, 2005; HSUS, Farm Sanctuary, Compassion Over Killing, \& Animals' Angels, 2005). This lack of enforcement led the HSUS and other animal welfare organizations to petition the United States Department of Agriculture (USDA), requesting that it engage in rulemaking to promulgate regulations applying the

\footnotetext{
${ }^{3}$ See 49 U.S.C. $\$ 80502$ (d). The Code of Federal Regulations provides that animals in holding pens shall have access to water and that all animals be given access to food if held longer than 24 hours (9 CFR $\$ 313.2$ (e)). When the USDA implemented its Food Safety and Inspection Service (FSIS) directive of August 15, 2011, regarding humane handling and slaughter of livestock, it provided that inspection program personnel (IPP) are required to ask establishment management whether the truck driver stopped to provide the animals with food, water, and rest if the animals appear exhausted or dehydrated (USDA FSIS, 2011). If the establishment or truck driver refuses to provide the queried information and the IPP
}

term "common carrier" to trucks (Brandt, 2005). In 2006, the USDA agreed that the plain meaning of the term "common carrier" included transport by truck. Nevertheless, the rule still exempts poultry.

In addition, the USDA claims it is not responsible for enforcing the rule, stating that enforcement is the responsibility of the Department of Justice. Moreover, the Animal and Plant Health Inspection Service (APHIS), which provides the rules and regulations for the Twenty-Eight Hour Law, does not require any sort of reporting or record-keeping on the part of truck drivers or

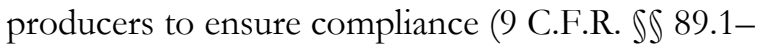
89.5). Equally troubling is that the law provides fines for violators in the amount of only US $\$ 100$ to US $\$ 500$ per truckload; thus there is a financial incentive to disregard the law and risk a minimal fine rather than comply. ${ }^{3}$ No criminal penalties are provided. For all intents and purposes, this rule provides scant protection to farm animals who travel up to-and often in excess of - 28 hours without food, water, or rest.

\section{The Federal Meat Inspection Act and the Humane Methods of Slaughtering Act}

The Federal Meat Inspection Act (FMIA) of 1906 regulates the production of meat and meat products from cattle, sheep, pigs, goats, and horses (21 USC $\int$ 601-695). Courts have interpreted how FMIA appears to govern which animals may be slaughtered, the conditions of the slaughterhouse, and how Food Safety Inspection Service (FSIS) inspectors must staff the slaughterhouses in a variety of scenarios. ${ }^{4}$ This Act further regulates how meat products should be labeled, packaged,

believe the animals' condition resulted from the deprivation of food, water, or rest, then IPP is required to contact the Animal and Plant Health Inspection Service (APHIS) so that APHIS can conduct an investigation (USDA FSIS, 2011).

${ }^{4}$ Compare National Meat Ass'n v. Harris, 132 S.Ct. 965, 973-974 (2012) (holding that California's proposed ban on the treatment, sale, and slaughter of nonambulatory animals was preempted by the FMIA, reasoning that the FMIA's scope includes which "animals that are going to be turned into meat" and which animals within the slaughterhouse "will never suffer that fate," but also reasoning that state bans on the butchering of horses for human consumption were not preempted 
and transported. The FMIA was enacted in response to the public uproar Upton Sinclair (1906) created upon publishing The Jungle, exposing the unsanitary and unsafe conditions in the United States' meat-packing industry. The Act is not, and was not, intended as an animal welfare statute. Rather, its intent is to protect the public interest by safeguarding "the health and welfare of consumers...by assuring that meat and meat food products distributed to them are wholesome, not adulterated, and properly marked, labeled, and packaged" (Congressional Statement, 21 U.S.C. \602).

Nevertheless, in 1978, the FMIA incorporated the Humane Methods of Slaughter Act (HMSA), which was originally enacted in 1958 (7 USC SS 1901-07). In order to comply with the FMIA, slaughterhouses were required to adhere to the HMSA. Citizens concerned with the welfare of livestock animals promoted the HMSA, which was intended to both protect slaughterhouse workers and safeguard the health and safety of the animals intended for slaughter (7 U.S.C. \1901). To that end, the HMSA provides "it is therefore declared to be the policy of the United States that the slaughtering of livestock and the handling of livestock in connection with slaughter shall be carried out only by humane methods" (7 U.S.C. $\$ 1901)$.

Two humane methods of slaughter are provided in the Act. The first requires that "cattle, calves, horses, mules, sheep, swine, and other livestock...[be] rendered insensible to pain by a single blow...that is rapid and effective, before being shackled...or cut" (7 U.S.C. \1902 (a)). The

because the latter ban "works at a remove from the sites and activities that the FMIA most directly governs), with Association des Eleveurs de Canards et D'Oies du Quebec v. Harris, 79 F. Supp. 3d 1136, 1147 (C.D. Cal. 2015) (relying on the Court's reasoning in National Meat Ass'n v. Harris to conclude that California's proposed ban on foie gras was preempted by the Poultry Products Inspection Act).

${ }^{5}$ FSIS issued a proposed rule titled "Modernization of Poultry Slaughter Inspection” on January 27, 2012 (see 77 FR 4408), which would have allowed slaughter facilities to increase their chicken line speeds to 175 birds per minute. Opposition from animal welfare groups such as Animal Welfare Institute (2010) and Farm Sanctuary were successful in preventing this change, due to several comments explaining that increasing the line second method involves slaughtering performed in accordance with the Jewish faith or another religious faith where the animal is rendered unconscious "by the simultaneous and instantaneous severance of the carotid arteries with a sharp instrument" (7 U.S.C. \$ 1902 (b)). Poultry are exempt (7 U.S.C. $\$ 1902$ (a)).

\section{The Poultry Products Inspection Act}

Similar to the FMIA, the Poultry Products Inspection Act (PPIA) of 1957 was not intended to regulate or promote the humane handling and welfare of poultry. Rather, the purpose of the PPIA is to protect "the health and welfare of consumers...by assuring that poultry products distributed to them are wholesome, not adulterated, and properly marked, labeled, and packaged" (21 U.S.C. \$ 451). The focus of the Act is on preventing "the burdening of [interstate] commerce by...poultry products which are adulterated or misbranded" (21 U.S.C. \452). Accordingly, the PPIA regulates the slaughter of chicken, ducks, geese, and turkey in interstate commerce with the above goals in mind. There are no specific provisions dictating the humane raising and slaughtering of these birds. A 2005 Notice to Poultry Processing by the FSIS declared, "there is no specific federal humane handling and slaughter statute for poultry" (Treatment of Live Poultry, 2005). The Notice merely provided that adherence to the PPIA "promotes humane slaughter" (USDA FSIS, 2005). It is difficult to understand FSIS's position when the PPIA itself contains no provisions explaining what constitutes the humane handling and slaughter of poultry. ${ }^{5}$ Thus, there is not a single federal

speeds creates more pressure on workers to shackle the birds faster, thereby increasing the likelihood of rough handling of the birds that could result in bruises and fractures. Decreasing the amount of time birds have to settle after being shackled and allowing less time in the water-bath stunner can result in large numbers of birds not being stunned fully or properly. If birds are not fully or properly stunned, they will miss the throat-cutting machine, which means they enter the scalding tank while still alive (Animal Welfare Institute \& Farm

Sanctuary, 2012). Due to consumer pressure and advocacy efforts, the final rule states that, with few exceptions, the line speed maximum is 140 birds per minute (USDA FSIS, 2014). Nevertheless, injury and inhuman handling still occurs at line speeds of 140 birds per minute. 
law regulating the humane treatment and care of animals raised for food in this country. The law intended to regulate the transport of animals raised for food is largely unenforced, while the laws intended to regulate the humane slaughter of animals are aimed more toward public health than ensuring the safety of billions of animals in the final moments of their lives (USDA, National Agricultural Statistics Service [USDA NASS], 2014). ${ }^{6}$

\section{Challenges to Regulating Animal Welfare at the State Level}

\section{Exemption and Preemption Problems}

Our federal statutes do a poor job of protecting animal welfare in this country. Many statutes exempt agricultural animals altogether or at least certain types of agricultural animals. The Animal Welfare Act-arguably the broadest and most sweeping of the federal animal welfare statutesspecifically exempts agricultural animals (7 U.S.C. \$ 2132 (g) [2008]). The Twenty-Eight Hour Law still exempts poultry. Given these shortcomings, it makes sense that states would try to fill in the gaps with legislation of their own.

However, a key problem states face if they try to pass welfare laws for animals raised for human consumption is the preemption clauses contained in federal statutes. For example, the FMIA contains an express preemption clause that prohibits states from enacting laws in addition to or different than the standards contained in the FMIA. Specifically, the FMIA provides that "requirements within the scope of this chapter with respect to premises, facilities and operations of any establishment... which are in addition to, or different than those made under this chapter may not be imposed by

\footnotetext{
${ }^{6}$ Red meat production in the U.S. totaled 49.3 billion pounds (22.3 billion $\mathrm{kg}$ ), including beef production of 25.8 billion pounds (11.7 billion kg), hog slaughter of 112.1 million head, and sheep slaughter of 2.32 million head (USDA NASSS, 2014a). In 2013, 8.52 billion broiler hens were slaughtered to produce 50.6 billion pounds (22.9 billion $\mathrm{kg}$ ) of meat; turkey production totaled 7.28 billion pounds ( 3.3 billion $\mathrm{kg}$ ); and egg production totaled 95.2 billion eggs (USDA NASS, 2014b). 7 When Congress passed the Wholesome Meat Act of 1967, it required that all meat sold across state borders be slaughtered,
}

any State" (21 USC S 678). The FMIA further preempts states from enacting any laws concerning "marking, labeling, packaging, or ingredient requirements in addition to, or different than" those contained in the FMIA (21 USC $\int 678$ ). ${ }^{7}$

This preemption clause posed an insurmountable hurdle for California when it passed a law that, among other things, barred slaughterhouses from processing, butchering, or selling meat or products from nonambulatory animals for human consumption (Cal. Penal Code $\ 599 \mathrm{f}(\mathrm{a}-\mathrm{c})$ [2010]). The Supreme Court held in National Meat Association v. Harris that the FMIA preempted the California law insofar as the FMIA allows for the butchering of nonambulatory animals and the California law does not. While the California law requires the immediate humane euthanasia of a nonambulatory animal, the FMIA allows for an FSIS inspector to inspect the nonambulatory animal and approve it for slaughter in the absence of disease or injury ( 9 CFR \ 309.1). Because the California law imposed different requirements on slaughterhouse premises, facilities, and operations with respect to the handling of nonambulatory livestock, the Court held that the FMIA “therefore precludes California's effort in $\int 599 \mathrm{f}(\mathrm{b})$ and (c) to impose new rules, beyond any the FSIS has chosen to adopt, on what a slaughterhouse must do with a [ivestock animal] that becomes nonambulatory during the production process" (National Meat v. Harris, 132 S. Ct. 965, 971 [2012]). Thus the FMIA imposes a ceiling, not a floor, concerning the welfare of livestock animals intended for slaughter; individual states may not impose animal welfare standards in excess of those contained in the federal law with regard to the geographical scope of the "premises, facilities

inspected, and processed in a federal facility (see 21 USCA SS $601,602,624,641-645,661,671-680,691)$. The intent was to ensure that all meat in the country was subjected to federal "high standards of inspection" to assure the American public that the meat was wholesome and safe; see Lyndon B. Johnson's 1967 address to Congress, "To Protect the American Consumer” (Peters \& Woolley, n.d.). The law favored federal standards of slaughter over state standards and eventually created a hurdle for states that later tried to create their own gold standards of slaughter and treatment of farm animals. 
and operations" that FSIS inspects. ${ }^{8}$

Similarly, the PPIA also contains an express preemption clause, stating that "requirements within the scope of this chapter with respect to premises, facilities and operations of any official establishment which are in addition to, or different than those made under this chapter may not be imposed by any State" (21 U.S.C. \467e). Further, the PPIA provides that "marking, labeling, packaging, or ingredient requirements (or storage or handling requirements found by the Secretary to unduly interfere with the free flow of poultry products in commerce) in addition to, or different than, those made under this chapter may not be imposed by any State" (21 U.S.C. $\$ 467 \mathrm{e})$. Thus, the PPIA is likely to preempt any state's attempts to legislate the conditions and treatment of poultry at slaughterhouses or processing plants in the same way that the FMIA preempted California's attempt to legislate the treatment of nonambulatory animals.

In contrast, the state of California has been successful so far in banning the sale of eggs produced from battery-caged hens. In 2008, California voters approved Proposition 2, a measure that prohibited egg producers within the state from using battery cages in their operations. The state legislature then passed Assembly Bill (AB) 1437, which prohibited the sale of eggs produced through the use of battery cages (Cal. Health \& Safety Code $\$ 25996)$. AB 1437 required out-ofstate egg farmers to comply with Prop. 2's requirements if they wished to sell their eggs in California. The legislative purpose of $\mathrm{AB} 1437$ is to "protect California consumers from the deleterious, health, safety, and welfare effects of the sale and consumption of eggs derived from egg-laying hens that are exposed to significant stress that may result in increased exposure to disease pathogens including salmonella" (Treatment of Animals 2010 Cal. Legis. Serv. Ch. 51, 25995 (e) [A.B. 1437]).

Shortly after the California legislature passed AB 1437, six states filed suit as plaintiffs (Missouri, Nebraska, Oklahoma, Alabama, Kentucky, and

\footnotetext{
${ }^{8}$ See Vesilind (2013).

${ }^{9}$ The parens patriae doctrine, translated as "parent of the country," allows states to become plaintiffs in litigation and
}

Iowa), challenging the law as unconstitutional under the Commerce and Supremacy Clauses of the United States Constitution (see Missouriv. Harris, 2014). The plaintiffs first alleged that $A B$ 1437 violated the Commerce Clause because it disrupted the free flow of interstate commerce. The plaintiffs next claimed that the Federal Egg Products Inspection Act (EPIA) expressly and impliedly preempted AB 1437. In addition, they alleged that forcing out-of-state egg producers to comply with California's statutory sales ban and accompanying regulations restricting the use of battery cages would result in higher egg costs that would be passed on to consumers.

Defendants in the suit included the attorney general of California and the Association of California Egg Farmers (ACEF) and the Humane Society of the United States (HSUS) as intervenors. The defendants moved to dismiss the plaintiffs' case, alleging that the plaintiffs lacked standing to sue in this instance. The plaintiffs had filed suit under the parens patriae ${ }^{9}$ standing doctrine, alleging that as states, they each had sovereign interests in protecting their citizens' economic health and constitutional rights.

The standing doctrine, which determines who may file suit in a given case, has developed over time through common law. Standing requires that a plaintiff meet three requirements in order to sue: (1) he or she has suffered an injury, (2) the defendant caused the injury alleged, and (3) the plaintiff can receive redress for the injury suffered through judicial resolution of the matter (see Lujan $v$. Defenders of Wildlife, 1992). In addition, for a state to be able to sue, it must demonstrate that is has a quasi-sovereign interest grounded in the well-being of its populace (see Alfred Snapp \& Sons, Inc. v. Puerto Rico, 1982). States have quasi-sovereign interests in the physical and economic health and well-being of their residents and in defending the constitutional rights of their residents. Parens patriae standing will exist where a state expresses a quasisovereign interest and also alleges injury to a sufficiently substantial segment of its population,

file lawsuits on behalf of their injured citizens (see Alfred Snapp \& Sons, Inc. v. Puerto Rico, 1982). 
and articulates an interest apart from the interests of particular private parties.

In Missouri vs Harris, the defendants moved to dismiss the plaintiffs' suit, alleging that the plaintiffs failed to demonstrate a quasi-sovereign interest. The defendants claimed that the plaintiffs were merely suing on behalf of a small portion of their populace- the egg producers in each individual state. Regarding plaintiffs' claim that dispensing with battery cages would result in rising egg costs, defendants asserted that such a claim was too speculative to meet the injury requirement of standing. The district court agreed with the defendants' position and dismissed the case without leave to amend, holding that the states lacked the necessary parens patriae standing to continue suit (see Missouri v. Harris, 58 F.Supp.3d at 1075, 1078, 2014).

Because the district court dismissed the case on procedural grounds due to a lack of standing, the court never reached the merits of the parties' arguments regarding the Commerce Clause or preemption under the Supremacy Clause. The plaintiffs appealed the district court's ruling and the appeal is currently pending before the Ninth Circuit. If the Ninth Circuit disagrees with the district court's standing analysis and reverses the ruling, then the case would proceed on its merits, and the district court would have to determine whether $\mathrm{AB} 1437$ violates the Commerce Clause or is preempted by the EPIA. Thus, it is still uncertain whether California will ultimately be successful in banning the sale of eggs produced from batterycaged hens.

Nevertheless, it seems that preemption in this situation is unlikely because California's egg law differs from its attempt to regulate nonambulatory animals in one critical respect. Nothing in the EPIA speaks to how the hens must housed, other than that the premises of each official plant must be kept in sanitary conditions (21 USC \ 1035). Thus the situation with battery cages is different that the situation with nonambulatory animals under the FMIA. Here, it is possible to comply with both $\mathrm{AB} 1437$ and the EPIA, thereby alleviating express preemption concerns. Further, because the EPIA contains only a general statement requiring sanitary conditions but no specific requirements regarding how to meet that standard, it does not seem that Congress intended to legislate this area so extensively such that it can be said to occupy the field and impliedly preempt state attempts to regulate here.

Similarly, nine states have been able to ban the use of gestation crates (Arizona, California, Colorado, Florida, Maine, Michigan, Ohio, Oregon, and Rhode Island) without any successful preemption challenges against their legislation. Arizona successfully banned the use of gestation crates by a ballot measure in 2006 with Proposition 204. Interestingly, Arizona's law was codified in the criminal section of its state code, an area of the law traditionally reserved to state power and usually free of preemption concerns (see Ariz. Rev. Stat. Ann. \13-2910.07). Moreover, state laws banning the use of gestation crates do not raise any preemption concerns under the FMIA because the FMIA is silent on how animals should be raised for slaughter. Rather, "FMIA's preemption clause is more naturally read as being concerned with the methods, standards of quality, and packaging that slaughterhouses use" (see Empacadora de Carnes de Fresnillo, S.A. de C.V.v. Curry, 476 F.3d 326, 333 [5th Cir. 2007]). Colorado's gestation ban was codified under the agriculture section of its state code, another area of law traditionally reserved to the states (see Colo. Rev. Stat. Ann. \ 35-50.5-101). Where there is not a federal law regulating safety aspects of a food product, such as the FMIA or the Food Safety Modernization Act (FSMA), states should have the authority to regulate animal welfare under their police powers. Thus, anticruelty laws whose purpose is to prevent suffering to animals should not encounter preemption problems.

\section{Commerce Clause Concerns}

\section{Dealing with the Affirmative Commerce Clause} Aside from the potential preemption problems states face if they try to regulate animal welfare, they also must take care not to run afoul of the Commerce Clause. The Commerce Clause contains the express delegation of authority from the Constitution to Congress to regulate commerce among the states (see U.S. Const. Art. I, $\int 8, \mathrm{Cl}$. 3). Thus, 
Congress can regulate all activities except those that are completely interior to a state, that do not in any way affect another state, or that Congress finds unnecessary to regulate (see generally Gibbons v. Ogden, 22 U.S. 1 [1824]). The Tenth Amendment to the Constitution provides "the powers not delegated to the United States by the Constitution, nor prohibited to it by the States, are reserved to the States respectively, or to the people" (U.S. Const. Amend. X). Accordingly, the federal government can only regulate those areas of the law that are expressly enumerated in the Constitution; all other powers are left to the states.

Whether a state law violates the Commerce Clause is an inquiry that has plagued legal practitioners and scholars for nearly two centuries. The Supreme Court has acknowledged that when states pass laws "not with a view or design to regulate commerce, but to [legitimately] promote some great object of public interest...such as the public health, agriculture, revenue, or the encouragement of some public improvement..., they are valid as internal regulations, though they may incidentally restrict or regulate foreign trade, or that between the States" (Gibbons v. Ogden, 22 U.S. at 72 [1824]). Therefore, a state law such as California's ban on the sale of eggs raised in battery cages seems to promote public health by intending to reduce the rates of salmonella-infected eggs and to raise agricultural animals in a more humane manner. Yet, "the power of Congress is 'to regulate commerce.' The correct definition of commerce is, the transportation and sale of commodities" (Gibbons v. Ogden, 22 U.S. at 76 [1824]). Because eggs are commodities traveling in interstate commerce, the Commerce Clause might reach AB 1437 after all. Later Commerce Clause case law holds that Congress can regulate "the use of the channels of interstate commerce...instrumentalities of interstate commerce [such as people and things, and]... activities having a substantial relation to interstate commerce" (see United States v. Loper, 514 U.S. 549, 558, 1995). This definition might also encompass $\mathrm{AB} 1437$ if the manner in which eggs are produced is construed as an activity substantially relating to interstate commerce.

On the other hand, Commerce Clause violations are usually found where the regulated activity has a direct effect on interstate commerce or where the regulated activity is inherently national and structural impediments could exist if states were left to create patchwork legislation (see A.L.A. Schechter v. United States, 1935). If the standing decision in Missouri v. Harris is reversed and the Commerce Clause issue is reached on remand, the court will have to employ a balancing test to consider whether the regulated activity (animal welfare) indirectly and remotely affects interstate commerce or whether it has such a close and substantial relation to interstate commerce that Congressional control is essential or appropriate to protect that commerce from burdens and obstructions by the state regulation (see NLRB $v$. Jones Laughlin Steel Corp. 301 U.S. 1 [1937]).

Here, it seems questionable whether changing how laying hens are housed would have a direct or substantial effect on interstate commerce, especially given that several large retailers have committed to sourcing $100 \%$ of their eggs from cagefree production facilities in the near future. Whether AB 1437 directly affects interstate commerce may soon be a moot question if the vast majority of egg producers move away from batterycage operations due to market demands. Additionally, the regulated activity (how egg-laying hens are housed) does not seem inherently national in nature. No federal statute governs how egg-laying hens should be housed or raised. Moreover, Congress has chosen time after time to purposefully exclude the treatment of agricultural animals from any federal animal welfare statutes and has chosen instead to limit federal regulation of animal food products largely to slaughter and inspection. Congress has not shown any interest in enacting a national policy safeguarding the welfare of animals raised for food in this country. The Constitution does not contain any express delegation of authority to the federal government to regulate animal welfare. Thus, under the Tenth Amendment, it would seem that animal welfare is an area that should be reserved to the states.

\section{Dealing with the Negative Commerce Clause}

If affirmative Commerce Clause concerns were not enough of an obstacle, state lawmakers must also contend with the evolution of the negative 
Commerce Clause doctrine. The negative (also called dormant) Commerce Clause is a legal doctrine arising under the Commerce Clause that deals with the question of whether, in the absence of a federal statute, there are inherent restrictions on state power such that it is appropriate to place limits on states' authority to regulate. Courts will invalidate state and local laws deemed to improperly interfere with interstate commerce. Here, the dormant Commerce Clause is implicated in the absence of a federal animal welfare statute that encompasses the humane treatment of agricultural animals.

Both political and economic theories provide the framework for modern dormant Commerce Clause analysis. Politically, state statutes that are incompatible with the ideal of a unified nation will be struck down. Economically, state protectionist statutes that would create the equivalent of Balkanized trade zones will also be struck down. Here, it seems that $\mathrm{AB} 1437$ would survive a dormant Commerce Clause challenge because the manner in which egg-laying hens are raised would not seem to disrupt a unified nation. By its failure to legislate, Congress has demonstrated that agricultural animal welfare is not a national concern. Similarly, from an economic perspective, the California law is not protectionist in nature. It is facially neutral, applying to in-state and out-of-state producers equally. Yet an argument could be made that outlawing the sale of battery-cage eggs in one state while permitting them in another could contribute to the creation of Balkanized trade zones. However, as noted before, the market as a whole seems to be tipping away from battery cages, so demand (and therefore production) of battery-cage eggs is likely to decrease, alleviating any trade zone concerns.

The dormant Commerce Clause jurisprudence has been murky at best, making it difficult for states to predict whether their laws are likely to be struck down. Justice Scalia readily admitted, "In the 114 years since the doctrine of the negative Commerce Clause was formally adopted as [a] holding of this Court... and in the 50 years prior to that in

10 This and many other commonly accepted agricultural practices are discussed in Farmed Animals and the Law, Animal which it was alluded to in various dicta of the Court...our applications of the doctrine have, not to put too fine a point on the matter, made no sense" (Tyler Pipe Indus., Inc. v. Wash. State Dep't of Revenue, 483 U.S. 232, 259-260 [Scalia, J., concurring in part and dissenting in part] [1987]). Thus, any state measure attempting to legislate the welfare of agricultural animals is likely to face a dormant Commerce Clause challenge, the outcome of which is uncertain.

\section{Current Laws Do Not Probibit Commonly Accepted Agricultural Practices}

Another challenge with our current regulatory framework is that federal and state animal cruelty laws do not prohibit commonly accepted agricultural practices (AAPs). Such practices include castration and tail-docking of pigs without anesthetics. Pigs are also kept in gestation crates while pregnant and farrowing crates while nursing, which prevent the mother sows from turning, lying down, or standing up. With respect to cattle, veal production is a necessary by-product of the dairy industry. Cows must be impregnated if they are to produce milk, but that milk cannot be used for human consumption if the baby calf consumes it, as nature intended. Thus, the calves are separated from their mothers, and the female calves are raised for the dairy operation while the male calves are housed in veal stalls. The males are restrained in isolation, prevented from walking and developing their muscles, and fed a deficient diet designed to keep them anemic. Poultry are subject to practices that would likely be considered abuse if they occurred to our companion cats and dogs. Debeaking involves cutting off chicks' beaks without anesthetic so they can be confined and crowded in cages without pecking their cagemates. Male chicks are tossed into chutes that grind them alive, as an unfortunate byproduct of the egg industry. Egglaying hens are routinely starved so that they produce more eggs in a process called forced molting. ${ }^{10}$ Nearly all animals raised for food are housed in crowded, unsanitary conditions without enough room to stand up, stretch, turn around, or engage

Legal Defense Fund (n.d.). 
in normal behavior for their species, such as nesting and roosting for hens and rooting for pigs.

Such overcrowding necessitates the use of antibiotics, which also increases the growth rates of the animals. Unfortunately and ironically, antibiotic use often causes the animals to become sick and develop painful abscesses (Conover, 2013).

Federal law does not prohibit these commonly accepted agricultural practices because they are, by name, "commonly accepted." The rational is that because we have been cruelly treating and torturing these animals in this way for so long, the cruelty and torture has somehow become sanctioned over time. The reality is that we are cruelly treating and torturing billions of animals every year, and "it is not simply more than...billion[s of] animals a year, but it is one, and one, and one, amounting to the large scale mistreatment of individual animals" (Wolfson, 1996, p. 133).

These commonly accepted agricultural practices are the antithesis to the Five Freedoms for animals that are recommended according to the Farm Animal Welfare Council (the Council). Great Britain established the Council in 1979 as an independent advisory group, with the intention to create a strategy to ensure animal welfare for agricultural animals. The Council sought to advance laws and policies intended to promote the Five Freedoms in the lives of animals raised for food in Great Britain. The Five Freedoms include ensuring that all agricultural animals are raised in ways that provide: (1) freedom from hunger and thirst, (2) freedom from discomfort, (3) freedom from pain, injury, or disease, (4) freedom to express normal behavior, and (5) freedom from fear and distress. The Council holds the philosophy that "at a minimum each farm animal should have a life that is worth living to the animal itself, and not just to its human keeper" (Farm Animal Welfare Council, 2009, p. 1).

The Five Freedoms provide a much better measure of animal welfare than our current commonly accepted agricultural practices. If we were to adopt the Five Freedoms as policy in this country, gestation and farrowing crates could no longer be used and veal sheds and battery cages for egg laying hens would be banned, as these practices prohibit animals from expressing normal behavior.
The way we transport and slaughter animals would need to drastically change to ensure that they are free from discomfort, pain, fear, and distress.

Last year the American Humane Association conducted a national survey and found that almost $94.9 \%$ of Americans were "very concerned" about the welfare of farm animals (American Humane Association, 2014). In a survey Consumer Reports conducted, $80 \%$ of respondents stated that they wanted animals raised for food to have good living conditions (Bopp, 2014). Given the overwhelming public support for improving the welfare of agricultural animals, it makes sense that the American public could convince large retailers like Walmart to do what Congress has not: enact an animal welfare policy based on the Five Freedoms, rather than on commonly accepted agricultural practices.

\section{A Solution to Filling in the Gap: Market Forces Are Driving Animal Welfare Conditions}

The market is finally responding to consumer demand for humanely raised animal products. Corporate America has been responding slowly, and at first the markets that were the most responsive were not those catering to the mainstream. Small, member-run food co-ops have been sourcing local, humanely raised animal products for some time, but they did not capture the average American consumer. The first significant corporate shift in favor of animal welfare began a decade ago when Whole Foods started selling only cage-free eggs in its stores (Whole Foods Market, Inc., 2008).

Whole Food's shift toward cage-free eggs demonstrated a tidal change toward more humane animal welfare standards. The company began working with the Global Animal Partnership (GAP), a nonprofit organization founded in 2008 with a mission of improving the lives of farm animals (GAP, n.d.). GAP consists of farmers, ranchers, advocacy groups, scientists, and retailers who work together to achieve better outcomes for animals raised for food. This diverse group created the 5-Step Animal Welfare Rating Program in an attempt to bring transparency to the grocery store so consumers could know how the animals were raised (GAP, n.d.).

The 5-Step program creates five levels of 
animal welfare, with different standards governing each level. The program is color-coded, allowing consumers an easy way to discern how farmers raised the animals. Step 1 is the lowest level of care provided to animals, which requires at a minimum that there be no cages, crates, or crowding. Step 1 would disqualify every concentrated animal feeding operation (CAFO) in this country. Step 2 refers to those farms that provide their animals with an "enriched environment," designed to provide engaging stimuli to animals that will ultimately reduce anxiety, boredom, and aggression. For example, enrichments for broiler hens include structures that allow birds to engage in natural behaviors such as foraging, scratching, and pecking. To that end, suitable enrichments would include bales of high, scattered grains, edible towers of food (broccoli, lettuce, eucalyptus branches, alfalfa, etc.), and various forage bins, boxes, and/or structures (GAP, 2014). Both Step 1 and 2 bear orange labels.

GAP Step 3 refers to products from farms that have allowed for "enhanced outdoor access," meaning that although animals might live in buildings, they all have access to the outdoors (Whole Foods Market, Inc., 2015a). To qualify for a Step 3 label, farms must allow four-week-old chickens continuous outdoor access during daylight hours, unless inclement weather conditions pose a risk to the birds (GAP, 2014). If chickens are slaughtered before four weeks of age, then they must have continual access to the outdoors for a minimum of two weeks prior to slaughter (GAP, 2014). Step 3 labels are yellow.

Step 4 labels indicate farms that have a "pasture-centered" operation, meaning that when animals live outdoors, they can engage in natural behavior for their species (e.g., rooting for pigs, foraging for chickens, and roaming for cattle) (Whole Foods Market, 2015a). Step 5 labels are used for "animal-centered" farms, which place the well-being of the animal above other concerns such as efficiency and economy (Whole Foods Market, 2015a). The program also defines a Step 5+ label that is reserved for those instances where the animal spends its entire life on one farm and all the other Step 5 conditions are met (Whole Foods Market, 2015a). These last three labels are all colorcoded green.
The GAP 5-Step program achieves better living conditions for farm animals than our federal laws do. All steps prohibit the use of commonly accepted agricultural practices, such as debeaking and toe trimming (GAP, 2012). With respect to cows, the steps require that they be allowed outdoor access during the finishing stage (GAP, 2014). Importantly, all steps provide for the welfare of chickens during transport, who are otherwise wholly exempted from the provisions set forth in the Twenty-Eight Hour Law. The 5-Step program even exceeds the requirements for other animals covered under the Twenty-Eight Hour Law by requiring that operators not withhold feed from chickens for more than 12 hours prior to slaughter (GAP, 2012).

The 5-Step program is remarkable in a number of other ways as well. First, all farms seeking a step label are audited every growing season (GAP, 2014). Second, only independent, third-party certifiers can conduct the audits, which promotes transparency and decreases the likelihood that a conflict of interest could affect the auditing process (GAP, 2014). Third, the standards for each step and species are open for public comment (GAP, n.d.). This public comment period allows for farmers, ranchers, scientists, and animal welfare behaviorists to provide feedback on any proposed welfare standards. In this way, GAP is functioning in a regulatory fashion, similar to how the USDA receives public comments for new rules it promulgates. However, USDA has refused to update the rules and regulations governing animal welfare, despite the fact that nearly $95 \%$ of Americans are "very concerned about farm animal welfare" and $76 \%$ of Americans stated that they are willing to pay higher prices for humanely raised meat, dairy, and egg products (American Humane Association, 2014).

Whole Foods' adoption of the 5-Step Program is laudable for trying to fill the gaps where federal and state animal welfare regulations fall short. However, known to many Americans as "Whole Paycheck," the chain represents a niche market in society, with prices that are often out of reach for the majority of Americans. Although recent surveys have demonstrated that at least three-quarters of Americans are now willing to pay a premium 
price in exchange for animal welfare, how much more Americans are willing to pay remains to be seen.

Perhaps it will not be long before other retailers, suppliers, and producers begin adopting the 5Step program. Slowly, we see other companies embracing animal welfare. Chipotle, a major player intent on revolutionizing the fast-food industry, caters to the mainstream population, unlike Whole Foods. Chipotle refuses to source from pig suppliers who use farrowing or gestation crates and slatted concrete floors without bedding.

Remarkably, Chipotle announced to consumers that it might not have pork for carnitas at all of its locations because it suspended one of its major pork suppliers for failing to follow its animal welfare standards (Charles, 2015). Chipotle's decision to remove carnitas from its menus in some locations demonstrates that it is inspecting its suppliers to ensure compliance with its animal welfare policies and is willing to discontinue relationships with suppliers who fail to comply.

Perhaps the largest tipping point of all is Walmart's recent announcement regarding its newly adopted animal welfare policy. Walmartthe largest food retailer in the U.S.—-is embracing the Five Freedoms in its new animal welfare policy (Cheeseman, 2015). Walmart (including its subsidiary Sam's Club) is asking its suppliers to:

- Report and take disciplinary and corrective action in cases of animal abuse;

- Find and implement solutions to address animal welfare concerns in housing systems, painful procedures, and euthanasia or slaughter;

- Promote transparency by providing progress reports to Walmart and publicly reporting against their own corporate animal welfare position on an annual basis;

- Adopt and implement the Judicious Use Principles of Antimicrobial Use from the American Veterinary Medical Association (AVMA), including accurate recordkeeping, veterinary oversight, and limiting antimicrobial treatment to animals that are ill or at risk;

- Adopt and implement Voluntary Guidance for Industry \#209 from the Food and Drug Administration in their own operations and their industry producer programs, including eliminating growth promotion uses of medically important antibiotics; and

- Promote transparency by providing a report on antibiotics management to Walmart and publicly reporting antibiotic use on an annual basis (Walmart Stores, Inc., 2015a).

Walmart's announcement "is the first time the retailer has established an official position on the treatment of animals used in its supply chain. As the largest grocery store in the U.S., the move by Walmart could bring more oversight and awareness of animal welfare throughout the industry" (Hadley, 2015). Every week, over 260 million customers shop at Walmart, and the company reported over US $\$ 136$ billion in sales for the 2015 fiscal year (Walmart Stores, Inc., 2015b). In contrast, Whole Foods reported US $\$ 15$ billion in sales for the 2015 fiscal year (Whole Foods Market, Inc., 2015b). If Walmart's suppliers actually adhere to the company's animal welfare policy, Walmart will achieve more for the welfare of agricultural animals in this country than all the federal and state laws combined.

However, it remains to be seen if Walmart will actually achieve the welfare aims listed in its new policy. The company is asking its suppliers to adhere to the welfare goals on a voluntary basis. It seems doubtful that companies will embrace Walmart's new animal welfare policy on a purely voluntary basis if Walmart does not intend to drop suppliers who are unwilling or unable to engage in more humane practices (as Chipotle has done). It has been well-documented that Tyson engages in harmful animal practices, in addition to having numerous labor and environmental violations (Food Chain Workers Alliance, 2015). Walmart's current method of monitoring Tyson and its other suppliers "is failing" (Food Chain Workers Alliance, 2015, p. 68). Given that Tyson is one of Walmart's largest poultry suppliers, it "should be held accountable to a strong labor and environmental code of conduct" (Food Chain Workers Alliance, 2015, p. 68). Yet Walmart has not enacted a plan to monitor or sanction Tyson for 
noncompliance with its animal welfare policy—at least not publicly.

There is a danger that Walmart could follow in Costco's footsteps and reap positive press for its stated commitment without engaging in any follow-through. In 2007, Costco announced that it would no longer source eggs from battery-caged hens (Gibson, 2015). However, Costco never created a timeline for when it wanted its suppliers to comply with its battery cage-free policy, nor did it require mandatory compliance from suppliers. Seven years later, the Humane Society of the United States released the results of an undercover investigation, demonstrating that a major Costco supplier (Hillandale Farms) was still caging hens in cramped conditions (Reuters, 2015). The undercover video footage revealed hens caged with deceased and decaying birds while broken eggs and dead chickens covered the floor (HSUS, 2015). Walmart has similarly failed to provide a timeline and require mandatory compliance from its suppliers. If Walmart wants to assure its customers that it values animal welfare, it should create a timeline for implementing its policy and require more than mere voluntary compliance.

Furthermore, if Walmart intends to promote transparency in its food supply chain, then it should enact a third-party certification scheme as Whole Foods has done. Relying on producers to voluntarily self-report risks creating another situation like Costco's. Using independent, thirdparty certifiers to verify compliance is a crucial component of any animal welfare policy. Better still, Walmart could consider becoming a GAP partner and joining the 5-Step program labeling scheme, which already uses independent, thirdparty certifiers.

Walmart's adoption of the Five Freedoms presents a unique opportunity to improve conditions for farm animals on a size and scale never before seen in this country. However, unless and until Walmart imposes a deadline, eliminates voluntary compliance, and requires third-party certification, animal welfare advocates and consumers should continue pressuring Walmart to hold the store accountable to its new policy. Animal welfare groups like Mercy For Animals and HSUS should continue investigating Walmart suppliers in the coming months to see if any suppliers are voluntarily complying with Walmart's policy.

Consumers should also be discerning and possess a healthy dose of criticism before purchasing animal products at a Walmart or other corporate chains like a Whole Foods. For customers who have the option of purchasing animal products from a local farm, through a community supported agriculture (CSA) share, or a local food co-op, these options are preferable in terms of assuring transparency and accountability. For example, consumers in Albany, New York, can choose to purchase meat from the local Honest Weight Food Co-Op, which is committed to selling meat from local, pastured, and humanely raised animals (Honest Weight Food Co-Op, 2015). The managers at Honest Weight personally visit the farms they source from and ensure compliance with their animal welfare standards; the co-op's relationship with many of its farmers dates back several decades. Rather than relying on Walmart's voluntary animal welfare scheme, where accountability is still questionable, consumers can purchase from a local food co-op that requires and verifies that suppliers comply with their animal welfare mandates. Similarly, consumers are more likely to observe animal conditions at a local market vendor's farm or a farm offering a CSA than at a Walmart or Whole Foods supplier. For the vast majority of consumers who do not live near local farms or food co-ops, Walmart may offer the best animal welfare option-but only if animal welfare advocates continue working to ensure that the option consumers believe they are getting based on Walmart's press release is truly a humanely raised product.

Walmart's animal welfare policy is significant not just in terms of the impact it will have on animals due to its market share, but also for its ability to influence other food retailers and restaurants to follow suit. Just months after Walmart announced its new policy, McDonald's declared that it was committing to sourcing all of its eggs from cagefree hens within 10 years (McDonald's, 2015). HSUS President and CEO Wayne Pacelle applauded McDonald's decision and noted how it was already having a cascading effect on several 
other large companies (Pacelle, 2015; Schroeder, 2016). Compass Group, Sodexo, Aramark, Burger King, Starbucks, Unilever, and now ConAgra have all made similar pledges to begin sourcing their eggs from battery cage-free operations (Pacelle, 2015). McDonald's is in a similar position to Walmart in terms of how it wields an incredible amount of market power. The operations supplying McDonald's in the U.S. and Canada alone provide the chain with over two billion eggs raised from eight million caged chickens every year (Pacelle, 2015). In light of McDonald's recent decision to begin serving breakfast all day, those numbers will likely increase (Strom, 2015).

McDonald's restaurants in Europe have already started sourcing battery cage-free eggs due to the pressure of animal welfare organizations like Compassion in World Farming (Pacelle, 2015). Pacelle notes that making advances for animal welfare are "driven by a combination of ballot measures, courtroom victories, corporate policies, public awareness campaigns, and innovations in agriculture" (Pacelle, 2015, para. 9). Public awareness campaigns must continue, as consumer pressure largely drives corporate policy. Two Mercy For Animals undercover investigations revealing horrific animal abuses at McDonald's egg suppliers in 2011 and 2013, and the subsequent petitions from hundreds of thousands of American and Canadian customers finally culminated in McDonald's announcement to source cage-free eggs (Solomon, 2015).

Although McDonald's has committed to a deadline of 2025, it has not explained how it will verify that its suppliers adhere to the new battery cage-free requirements. Moreover, there is the risk that egg suppliers will simply convert crowded battery caged conditions to crowded tunnels that still do not allow for adequate access to light, the outdoors, perches, and stimulation. Nevertheless, eliminating battery cages is an important first, incremental step in improving the lives and wellbeing of millions of farm animals—so long as suppliers actually comply.

\section{Conclusion}

Mainstream consumers are growing concerned about the food they are placing on the dinner table.
Parents worry about the antibiotics and hormones in the food they feed to their children. The public is outraged when undercover videos of CAFOs reveal the horrific abuses inherent in the meals we consume three times a day. Despite this shift in public opinion, federal legislation has thus far been unresponsive and wholly ineffective at safeguarding the care, transport, and slaughter of animals raised for food in this country. At worst, attempts at state regulation have largely fallen short; at best, these attempts often face uncertain and expensive legal challenges. In the face of a Congress that lacks the political will necessary to effectuate meaningful change, consumers and animal advocates have placed increasing pressure on industry. In response to a myriad of consumer concerns, some restaurants and retailers are trying to encourage more humane methods of raising animals for food. Now, in response to consumer pressure, the company with arguably the most capital and market power in America has officially embraced animal welfare and the Five Freedoms.

Malcolm Gladwell explains that "the name given to that one dramatic moment in an epidemic when everything can change all at once is the Tipping Point" (Gladwell, 2002, p. 9). We are now standing at the precipice of another tipping point. The retail and restaurant industries, at their customers' urging, are steering us toward a tipping point where we may finally start to see some chinks in the armor that has always surrounded the factory farming method. Walmart could lead the charge.

However, there are serious flaws in Walmart's animal welfare policy. The lack of a deadline, the nature of voluntary compliance, and the absence of third-party certifiers could all ruin what would otherwise be an important step forward in the animal welfare realm. Now is no time for complacency. More than ever, consumers and animal welfare activists must maintain their advocacy efforts to hold Walmart accountable and ensure that its suppliers, like Seaboard Foods and Tyson, adhere to the principles set forth in the Five Freedoms.

Other companies, such as McDonald's, are starting to follow Walmart's lead. These companies also need deadlines for mandatory compliance, as well as third-party certifiers to verify that compliance. Walmart's animal welfare proclamation is a 
laudable first step forward, but consumer pressure and momentum must continue building to ensure follow-through. Consumer demands, animal welfare advocacy, and shifting corporate policies are creating a synergistic recipe for change. If our food system is to tip in favor of animal welfare and sway away from factory farming, now is the time.

\section{References}

A. L. A. Schechter Poultry Corp. v. United States, 295 U.S. 495 (1935).

Alfred Snapp \& Sons, Inc. v. Puerto Rico, 458 U.S. 592, 594 (1982).

American Humane Association. (2014). Humane Heartland farm animal welfare survey. Retrieved from http://www.americanhumane.org/humaneheartland/2014-humane-heartland-farm-survey.pdf

Animal Legal Defense Fund. (n.d.) Farmed animals and the law. Retrieved from http://aldf.org/resources/advo cating-for-animals/farmed-animals-and-the-law/

Animal Welfare Act of 1966 (Pub. L. No. 89-544, 80 Stat. 350, codified as amended at 7 U.S.C. SS 21312159 [2008]).

Animal Welfare Institute. (2010). Legal protections for farm animals during transport. Retrieved from https://awionline.org/sites/default/files/uploads/ legacy-uploads/documents/FA-LegalProtections DuringTransport-081910-1282577406-document23621.pdf

Animal Welfare Institute \& Farm Sanctuary. (2012, May 17). Comment letter. Retrieved from http://chickenjustice.org/wp-content/uploads/ 2013/07/Animal-Welfare-Inst.pdf

Ariz. Rev. Stat. Ann. \13-2910.07.

Bopp, S. B. (2014, August 27). It's only natural, but what does that mean? Retrieved from http://www.cattle network.com/cattle-news/Its-only-natural-butwhat-does-that-mean--272860091.html

Brandt, P. (2005, October 4). Loopholes on wheels: Trucks and the 28-Hour Law. The Humane Society of the United States.

Cal. Penal Code \599f (a-c) (2010).

Charles, D. (2015, January 19). Chipotle's pulled pork highlights debate over sow welfare. National Public Radio. Retrieved from http://www.npr.org/ sections/thesalt/2015/01/16/377760603/chipotles -pulled-pork-highlights-debate-over-sow-welfare

Cheeseman, G.-M. (2015, May 25). Walmart adopts groundbreaking animal welfare policy. Retrieved from http://www.triplepundit.com/2015/05/ walmart-adopts-groundbreaking-animal-welfarepolicy/

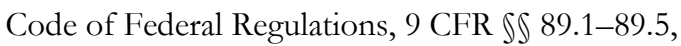
313.2 (e).

Colo. Rev. Stat. Ann. \ 35-50.5-101.

Congressional Statement of Findings, 21 U.S.C. $\int 602$.

Conover, T. (2013, May). The way of all flesh: Undercover in an industrial slaughterhouse. Harper's Magazine. Retrieved from https://harpers.org/ archive/2013/05/the-way-of-all-flesh/

Egg Products Inspection Act (EPIA), 21 USC \ 1035.

Empacadora de Carnes de Fresnillo, S.A. de C.V. v. Curry, 476 F.3d 326, 333 [5th Cir. 2007]).

Farm Animal Welfare Council. (2009). Farm animal welfare in Great Britain: Past, present and future. London: Author. Retrieved from https://www.gov.uk/government/groups/ farm-animal-welfare-committee-fawc

Federal Meat Inspection Act (FMIA) of 1906, 21 USC $\int 601-695$.

Food Chain Workers Alliance. (2015, June 4). Walmart at the crossroads: The environmental and labor impact of its food supply chain. Retrieved from http:// foodchain workers.org/wp-content/uploads/2015/06/ Walmart-at-the-Crossroads-FINAL-06.04.15.pdf

Friedrich, B. (2013, March 16). The cruelest of all factory farm products: Eggs from caged hens. Retrieved from http://www.huffingtonpost. com/bruce-friedrich/eggs-from-cagedhens b 2458525.html

Gibbons v. Ogden, 22 U.S. 1 (1824).

Gibson, K. (2015, June 17). Safety issues raised as Costco won't commit to cage-free eggs. CBS News. Retrieved from http://www.cbsnews.com/news/ safety-issues-raised-as-costco-wont-commit-tocage-free-eggs/

Gladwell, M. (2002). The tipping point: How little things can make a big difference. New York: Back Bay Books.

Global Animal Partnership. (n.d.). About us. Retrieved from http://www.globalanimalpartnership.org/ about

Global Animal Partnership. (2012). 5-Step animal welfare rating standards for chickens raised for meat. Retrieved from http://glblanimalpartnership.blob.core. windows.net/standards/Chicken $\% 20$ Welfare $\% 20$ $\underline{\text { Standards.pdf }}$ 
Global Animal Partnership. (2014). Pilot GAP policy manual. Retrieved from https://glblanimalpartner ship.blob.core.windows.net/other/GAP\%20Policy \%20Manual.pdf

Hadley, M. (2015, May 22). Walmart pushes stricter animal welfare policy. USA Today. Retrieved from http://www.usatoday.com/story/money/2015/05 /22/walmart-animal-welfare-policy/27772285/

Honest Weight Food Co-op. (2015). Honest Weight Food Co-op food and product manual. Retrieved from http://www.honestweight.coop/uploads/pdf/ 1429713102 Food and Product Manual 2-222015.pdf

Humane Methods of Slaughter Act (HMSA) of 1958, 7 USC SS 1901-07.

Humane Society of the United States [HSUS]. (2005, October 4). Petition for rulemaking before the United States Department of Agriculture. Retrieved from http://www.fsis.usda.gov/wps/wcm/connect/9dd d8b7c-983f-4cb1-83e8-9e545e9345d0/Petition HSUS Humane Handling.pdf?MOD=AJPERES

HSUS. (2014, February 19). Crammed into gestation crates. Retrieved from http://www.humanesociety.org/ issues/confinement farm/facts/gestation crates. $\underline{\mathrm{html}}$

HSUS. (2015, June 9). Undercover exposé: Inhumane treatment of animals, food safety concerns at Costco egg supplier: Film reveals live birds crammed into small cages with dead birds [Press release]. Retrieved from http://www.humanesociety.org/news/press releases/2015/06/inhumane-treatment-costcoegg-supplier-060915.html

Humane Society of the United States [HSUS], Farm Sanctuary, Compassion Over Killing, \& Animals' Angels. (2005, August). Petition for rulemaking before the United States Department of Agriculture. Retrieved from http://cok.net/wp-content/uploads/2013/ 02/Twenty-Eight-Hour-Law-Petition-2005.pdf

Jones v. Rath Packing Co., 430 U.S. 519, 538 (1977).

Lujan v. Defenders of Wildlife, 504 U.S. 555, 560 (1992).

McDonald's. (2015, September 9). McDonald's to fully transition to cage-free eggs for all restaurants in the U.S. and Canada. Retrieved from http://news.mcdonalds. com/Corporate/news-stories/2013/McDonaldsto-Fully-Transition-to-Cage-Free-Eggs

Mercy For Animals. (2015). Undercover investigations. Retrieved from http://www.mercyforanimals. org/investigations
Missouri v. Harris, 58 F. Supp. 3d 1059 (E.D. Cal. 2014).

National Meat Association v. Harris, 132 S. Ct. 965, 971 (2012).

NLRB v. Jones Laughlin Steel Corp., 301 U.S. 1 [1937]).

Pacelle, W. (2015, September 9). Breaking news:

McDonald's announces cage-free commitment for laying hens [Blog post]. Retrieved from http://blog.humanesociety.org/wayne/2015/09/ mcdonalds-announces-cage-free-commitment-forlaving-hens.html

Peters, G., \& Woolley, J. T. (n.d.). Lyndon B. Johnson, 57 Special Message to the Congress "To Protect the American Consumer," February 16, 1967. Retrieved from The American Presidency Project, http://www.presidency.ucsb.edu/ws/?pid $=28638$

Pike v. Bruce Church, Inc., 397 U.S. 137, 142 (1970).

Poultry Products Inspection Act (PPIA) of 1957, 21 U.S.C. $₫ 451-452$.

Reuters. (2015, June 9). 'Inhumane' conditions found at egg supplier for Costco. The New York. Times. Retrieved from http://www.nytimes.com/2015/ 06/10/business/inhumane-conditions-found-ategg-supplier-for-costco.html? $\mathrm{r}=1$

Rice v. Santa Fe Elevator Corp., 331 U.S. 218, 230 (1947).

Schroeder, E. (2016, January 19). ConAgra commits to cagefree. Retrieved from http://www.foodbusiness news.net/articles/news_home/Business_News/20 16/01/ConAgra_commits_to_cage-free.aspx?ID $=\% 7 \mathrm{~B} 996953 \mathrm{DB}-680 \mathrm{C}-4 \mathrm{C} 60-8 \mathrm{~A} 37-0 \mathrm{E} 133 \mathrm{~B} 2654$ FD $\% 7 D \& c c k=1$

Shanker, D. (2015, December 28). Egg-cellent: After months of pressure, Costco commits to a cage-free egg supply.

Retrieved from http://qz.com/582427/aftermonths-of-pressure-costco-commits-to-a-cage-freeegg-supply/

Sinclair, U. (1906). The jungle. New York: Doubleday, Page.

Solomon, A. (2015, September 9). McDonald's adopts cage-free egg policy following Mercy For Animals investigations [Blog post]. Retrieved from http://www.mfablog.org/mcdonalds-adopts-cagefree-egg-policy-following

Strom, S. (2015, September 9). McDonald's plans a shift to eggs from only cage-free hens. The New York Times. Retrieved from http://www.nytimes.com/ 2015/09/10/business/mcdonalds-to-use-eggsfrom-only-cage-free-hens.html?_ $r=0$ 
Treatment of Animals - Shelled Eggs - Sale for Human Consumption, 2010 Cal. Legis. Serv. Ch. 51 (A.B. 1437); Cal. Health \& Safety Code \ 25996.

Twenty-Eight Hour Law of 1873, 49 U.S.C. \ 80502 (a) (1) (1994).

Tyler Pipe Indus., Inc. v. Wash. State Dep't of Revenue, 483 U.S. 232, 259-260 (1987) (Scalia, J., concurring in part and dissenting in part).

U.S. Const. Amend. X.

U.S. Const. Art. I, \ 8, Cl. 3.

U.S. Department of Agriculture, Food Safety and Inspection Service [USDA FSIS]. (2005). Treatment of live poultry before slaughter (Federal Register Volume 70, No. 187). Retrieved from http://www.fsis.usda. gov/OPPDE/rdad/FRPubs/04-037N.htm

USDA FSIS. (2011, August 15). Food Safety and Inspection Service Directive 6900.2 Revision 2, Humane handling and slanghter of livestock. Retrieved from http://www.fsis. usda.gov/wps/wcm/connect/2375f4d5-0e24-4213902d-d94ee4ed9394/6900.2.pdf?MOD=AJPERES

USDA FSIS. (2014, August 21). Modernization of poultry slaughter inspection; Final rule. Federal Register, 79(162), 49565-49637. Retrieved from http://www.fsis.usda.gov/wps/wcm/connect/fb8c 866a-a9b7-4b0d-81c9-0f190c4a8d4d/2011-0012F. htm?MOD=AJPERES

USDA, National Agricultural Library. (n.d.). Government and professional resources. Retrieved from http://awic.nal.usda.gov/government-andprofessional-resources

USDA, National Agricultural Statistics Service [USDA NASS]. (2014a). Livestock slaughter 2013 summary. Retrieved from http://usda.mannlib.cornell.edu/ MannUsda/viewDocumentInfo.do?document $\underline{\mathrm{ID}=1097}$

USDA NASS. (2014b). Poultry-Production and value 2013 summary. Retrieved from https://usda.mannlib. cornell.edu/usda/nass/PoulProdVa//2010s/ 2014/PoulProdVa-04-29-2014.pdf

United States v. Lopez, 514 U.S. 549, 558 (1995).

Vesilind, P. A. (2013). Preempting humanity: Why National Meat Ass'n. v. Harris asked the wrong question (65 Me. L. Rev. 685). Retrieved from http://papers.ssrn. $\mathrm{com} / \mathrm{sol} 3 /$ papers.cfm?abstract $\mathrm{id}=2280430$

Walmart Stores, Inc. (2015a, May 22). W almart U.S. announces new animal welfare and antibiotics positions: Company outlines expectations for suppliers to W almart U.S. and Sam's Club U.S., as part of commitment to sustainable supply chain [Press release]. Retrieved from http://news.walmart.com/news-archive/2015/05/ 22/walmart-us-announces-new-animal-welfare-andantibiotics-positions

Walmart Stores, Inc. (2015b). Financial facts. Retrieved from http://corporate.walmart.com/newsroom/ company-facts

Whole Foods Market, Inc. (2008, March 17). Eggs in purgatory. Retrieved from http://www.wholefoods market.com/blog/whole-story/eggs-purgatory

Whole Foods Market, Inc. (2015a). Animal welfare standards. Retrieved from http://www.whole foodsmarket.com/about-our-products/qualitystandards/animal-welfare-standards

Whole Foods Market, Inc. (2015b). Whole Foods Market prices $\$ 1.0$ billion senior notes offering. Retrieved from http://assets.wholefoodsmarket.com/www/ company-info/investor-relations/financial-pressreleases/2015/20151130-WFM-Bond-PR.pdf

Wholesome Meat Act of 1967, 21 USCA SS 601, 602, 624, 641-645, 661, 671-680, 691.

Wolfson, D. J. (1996). Beyond the law: Agribusiness and the systemic abuse of animals raised for food or food production. Animal Law, 2, 123-154. 